\title{
CLOSING REMARKS
}

\author{
By J. W. GLEN
}

(Department of Physics, University of Birmingham, Birmingham B 152 TT, England)

SPEAKING on behalf of the rather informal international group who correspond and decide whether to have a symposium, I want to say now, formally in the Symposium, what I said during the dinner last night to express our thanks to the International Glaciological Society for having so readily agreed when we asked them not only to sponsor but also to organize this Symposium. I suspect all the participants here will want to join us to say a very sincere thank you to the people in Cambridge who have had to organize this Symposium and who have carried this out unobtrusively. In a smoothly running symposium you do not see how much work has to be done, but I know how much work is involved and we are all very grateful to the Society office, particularly Hilda Richardson, Secretary General, Beverley Baker, and the other members of their group who have not only done the administrative work connected with the circulars and the Papers Committee but also have arranged for the meeting rooms, accommodation, the dinner, and all the details. I want therefore to thank the President and Secretary General of the Society and through them all the others involved. 